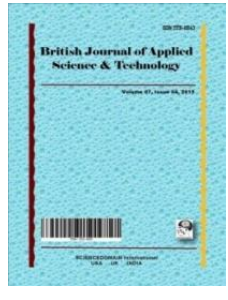

British Journal of Applied Science \& Technology

10(1): 1-10, 2015, Article no.BJAST.18194

ISSN: 2231-0843

SCIENCEDOMAIN international

www.sciencedomain.org

\title{
Dormancy Breaking of the Fig Tree with Hydrogen Cyanamide and Garlic Extrate
}

\author{
Sarita Leonel ${ }^{1}$, Marco Antonio Tecchio ${ }^{1 *}$ \\ and Giovanni Marcelo De Angeli Gilli Cóser ${ }^{1}$ \\ ${ }^{1}$ Horticulture Department, São Paulo State University, São Paulo, Brazil.
}

Authors' contributions

This work was carried out in collaboration between all authors. Author SL designed the study. Authors SL, MAT and GMDAGC jointly managed the analyses of the study and managed the literature searches. Author MAT was responsible for the statistical analysis of data. All authors read and approved the final manuscript.

Article Information

DOI: 10.9734/BJAST/2015/18194

Editor(s):

(1) Ahmed Mohamed El-Waziry, King Saud University, College of Food and Agriculture Sciences, Kingdom of Saudi Arabia. Reviewers:

(1) Ishola Vincent, IFaculty of Agriculture, University of Abomey-Calavi, Benin

(2) Zhao Chen, Department of Biological Sciences, Clemson University, USA.

Complete Peer review History: http://www.sciencedomain.org/review-history.php?iid=1210\&id=5\&aid=9647

Original Research Article

Received $8^{\text {th }}$ April 2015

Accepted $14^{\text {th }}$ May 2015

Published $8^{\text {th }}$ June 2015

\section{ABSTRACT}

The supply of cold hours needed to the dormancy breaking of shoots is the limiting factor for the cultivation of temperate climate fruit trees in warmer regions. In subtropical conditions, it is necessary to use chemical products to promote uniform sprouting. This research aimed at evaluating the effect of garlic extract and hydrogen cyanamide in sprouting, growth, production and production cycle of the fig tree. The experiment was conducted during the production cycles of 2011/12 and 2012/13. We used plants from the cultivar Roxo de Valinhos. Production pruning was made in the months of July/2011 and July/2012, and the following treatments were applied immediately after it: $2 \%$ hydrogen cyanamide and garlic extract in $4 \%, 8 \%$ and $12 \%$ doses, and a control treatment. Split plots were used as the experimental design, with five repetitions in blocks; each plot consisted of five treatments with hydrogen cyanamide, garlic extract and control; the subplots consisted of two production cycles. The use of hydrogen cyanamide promoted an anticipation of sprouting and the use of hydrogen cyanamide and garlic extract promoted a concentration of the productive period, when compared to the control. The estimated garlic extract dose that promoted the highest production per plant was $3 \%$. 
Keywords: Ficus carica L.; sprouting; fructification; production.

\section{INTRODUCTION}

The fig tree is native to Asia Minor and Syria, in the Mediterranean region, and was first cultivated and selected by the Arabs and Jews in Southwest Asia. The Mediterranean climate predominates in the fig tree's region of origin, and it is characterized as a temperate subtype climate, with temperature variations in the coldest month ranging from $-3^{\circ} \mathrm{C}$ to $18^{\circ} \mathrm{C}$, with dry, hot summers and rainy, cold winters, with improbable occurrence of snow in winter [1].

The fig tree is well adapted to different climates and it is cultivated in subtropical and temperate regions [2], because it is a native plant of a region with predominant subtropical climate. The fig trees seems to have not deep dormancy in comparison with other species like cherry and apple in the same country [1] and adapts to regions that have from 0 to 150 hours of $\leq 7,2^{\circ} \mathrm{C}$ temperatures [3], or with continuous exposition time equivalent to four days/cycle of temperatures below this limit [4]. However, this temperature values should not be considered a limiting factor for the stagnation of the plant's metabolic activities [3].

The cultivation of the fig tree in warmer climate regions has proved a viable alternative, as there is good plant growth and good productivity.

The temperature is closely linked to the growth and development of the fig tree, because there is a minimum, maximum and an optimal temperature range for each cultivar. Thus, dormancy fructification, ripening and quality of fruits all depend (in their own time) on a certain thermal time [2]. For the climate conditions of Botucatu (São Paulo state; henceforth SP), in four sequential production cycles, the authors verified the minimum basal temperature $\left(T_{b}\right)$ and maximum basal temperature $\left(T_{B}\right)$ of $8^{\circ} \mathrm{C}$ and $36^{\circ} \mathrm{C}$, respectively. These results corroborate the available reports, which indicate the planting of fig trees in regions that are warmer than the traditional ones $[5,6]$. According to these authors it still particularly characterised by a high requirements of spring and summer temperatures for rapid growth. Hence, sucessfull cultivation of fig trees is possible if a warm growing season is followed by a relatively cold winter to break dormancy [1].
In Brazil, the fig tree is cultivated in a system of annual drastic pruning, which condition the number of productive branches and the plant growth. Because of that, the cycle is measured according to the number of days from the pruning to the harvest period. Souza et al. [2] conducted a study in the climate conditions of Botucatu (SP), in four evaluation cycles (from 2002 to 2005), and found that the production cycle varied between 77 and 118 days, depending on the evaluation year. According to the authors, the thermal need for the fig tree 'Roxo de Valinhos' to develop from the pruning, made in July and August, until the harvest period, was, on average from 2.220 to 1.995 degree-days.

The Brazilian production of the 'Roxo de Valinhos' fig spreads from regions of colder climate (subtropical and e altitude tropical), such as Rio Grande do Sul state, Sao Paulo plateau and South of Minas Gerais state, up to hot regions in the North of Rio de Janeiro state, the South of Espírito Santo state and Vale do São Francisco. These places are preferred because of the plant's little or no demands for cold to complete the rest period, combined with the high amplitude between the limiting temperature extremes [7].

In subtropical climate regions, the accumulated cold hours needed for the dormancy breaking are commonly not fully satisfied. Under the inadequacy of accumulated cold hours, it is common to use chemical products that present effects on dormancy breaking and that act as sprouting inducers [8]. The hydrogen cyanamide is used in situations of lack of cold hours in the winter, and when it is needed to standardize and anticipate sprouting, and to stimulate, because of that, the early harvest. Its mode of action is not entirely clear, and may be related to the effects on the respiratory system of cells and the interference with some enzymatic processes that control the plant's rest, such as the catalase activity [9].

Although the hydrogen cyanamide is the most effective compound in dormancy breaking [10], the necessity of increasingly lower the use of synthetic and toxic substances on trees (in order to prefer sustainable systems of production) makes the chemical dormancy breaking of fruit trees a limiting factor for the activity in the world $[11,12]$ and also in Brazil $[13,14]$. 
In the search for new alternatives to break dormancy of fruit plants in temperate climate, Kubota and Miyamuki [15] conducted a study on the use of garlic paste on grapevines. The authors substantiate the hypothesis of using the product due to the presence of active substances - it contains sulfur and an allyl group $\left(\mathrm{H}_{2} \mathrm{CHCH}_{2}\right)$, mainly the diallyl disulfide, which is the most abundant sulfate in garlic, and would act by the same mechanism proposed by Pinto et al. [16], on the dormancy breaking of temperate climate plants, that is, through oxidative stress via accumulation of $\mathrm{H}_{2} \mathrm{O}_{2}$, consequently enabling promising results in the plants' growth. Kubota et al. [17] continued the research, and found that the application of pure garlic paste or garlic oil promoted dormancy breaking of shoots and grapevines. In Brazil, Botelho et al. [18] also reported the favorable use of garlic extract on the sprouting induction in apple trees.

Garlic extract is a natural product that works as an alternative for the dormancy breaking of temperate climate fruit trees, mainly for alternative production systems, which restrict the use of agrochemicals [14].

There are no reports on the use of garlic extract as a sprouting inductor on fig trees under the growing conditions in subtropical climate of the State of São Paulo. There is a need for studies to enable the recommendation of this product. In recent years, the popular interest in consuming fresh fruits has increased, mainly due to the large presence of bioactive compounds $[19,20]$. At the same time, there is the interest in organic production systems or with minimal use of synthetic chemicals. Considering that there are no available reports about the need of chemical products for dormancy breaking in subtropical climate conditions, this study had the objective of evaluating the effects of applying garlic extract and hydrogen cyanamide in sprouting, production and productive cycle of the fig tree cv. Roxo de Valinhos, in Botucatu (SP).

\section{MATERIALS AND METHODS}

The study was conducted at the Experimental Farm Lageado, at the School of Agricultural Sciences of the São Paulo State University UNESP, situated at $22^{\circ} 51^{\prime} 47^{\prime \prime} \mathrm{S}, 48^{\circ} 25^{\prime} 12^{\prime \prime} \mathrm{W}$ and at $810 \mathrm{~m}$ altitude. The climate in the region is mesothermal, according to Köppen climate classification [21], or Cwa, which means it is humid subtropical, dry in the winter and rainy in the summer. The average annual rainfall is 1,314 $\mathrm{mm}$. The relative humidity is $75 \%$ and the average temperature in the coldest month (July) is $17.1^{\circ} \mathrm{C}$, and $23.3^{\circ} \mathrm{C}$ in the hottest month (February); the average annual temperature is $20^{\circ} \mathrm{C}$ [22]. The area's soil is classified as Red Alfisol.

We used plants from the cultivar Roxo de Valinhos, which were planted on September 5, 2010; their seedlings came from the Seedling protection Center of CATI, in the city of Tietê (SP). The experimental design used was the split pot, with five repetitions in blocks and three useful plants per experimental plot; the each plot corresponded to the five treatments: $2 \%$ hydrogen cyanamide (dormex) [5,23] and Biogarlic ( $70 \%$ garlic extract) in doses of $0 \%, 4 \%$, $8 \%$ and $12 \%$. The subplots were composed of two evaluation cycles, corresponding to the years of 2011-12 and 2012-13. We evaluated 75 plants, which were two years old in the production cycle of 2011/2012 and three years old in the cycle of 2012/2013; they were cultivated in spacings of $3.0 \mathrm{~m}$ between rows and $2.0 \mathrm{~m}$ between plants.

We carried out cultivation and phytosanitary practices in the experiment, according to cultivation technical recommendations [24]. Pruning was made in the beginning of July, in 2011 and 2012, preceding the products that were applied immediately after the fructification pruning. For both hydrogen cyanamide and garlic extract, the application was made with a knapsack sprayer, with 3 liters of solution per plant, with the aid of a plastic curtain, so that there was no driftage.

In the production cycles of 2011/12 and 2012/13, it were evaluated the average number of shoots per plant, the average diameter of the productive branches (in millimeters), the number of fruits, the fresh mass of fruits (in grams), the longitudinal diameter (LD) and equatorial diameter (ED) of fruits, in millimeters $(\mathrm{mm})$, the relation ED/LD, the production ( $\mathrm{kg}$ per plant $\left.{ }^{-1}\right)$, the length of the production cycle (period from the date of pruning to the fructification peak, in days) and the length of the productive period from the beginning to the peak and end of harvests. These results were defined according to the dates and number of harvests made and to the obtained production. The fruits were harvested once (or almost every time) they reached an average weight of 50 to $60 \mathrm{~g}$.

The results were submitted to analysis of variance; the mean values of treatments on each of the plots (garlic extract and hydrogen 
cyanamide) and subplots (production cycles) were compared by the Tukey test at $5 \%$ significance level. Data related to garlic extract doses were submitted to polynomial regression analysis. The data on the tables and graphs were the average from two years of the experiment. The software used for the analyses of variance was SISVAR [25].

\section{RESULTS AND DISCUSSION}

There was no significant interaction between the compounds to overcome the dormancy and the production cycles for any of the evaluated variables; however, the treatments showed isolated effects. This way, we considered the mean values obtained in the evaluation cycles (2011/12 and 2012/13) for all of the evaluated variables.

We have found that the plants that were subjected to $2 \%$ hydrogen cyanamide had their fruit harvest anticipated, when compared to the control treatment, with a cycle of 98 days. This confirms the results reported in literature $[10,8,16]$, which state the efficiency of this product in the promotion, standardization and anticipation of sprouting (Table 1). However, the values obtained on the $2 \%$ hydrogen cyanamide treatment did not differ from the use of 4,8 and $12 \%$ garlic extract, which led us to suggest the use of this compound as a sprouting inducer for

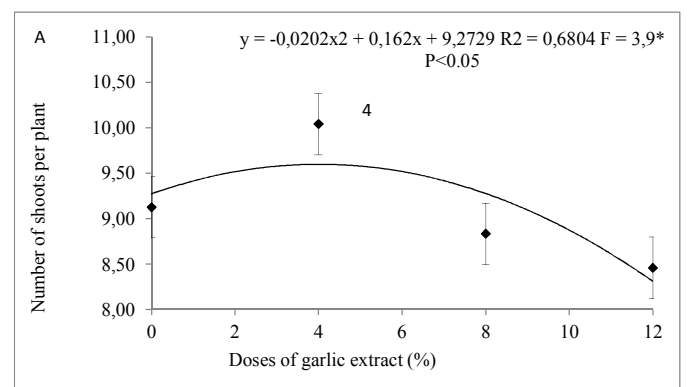

fig trees. By the regression analysis, we adjusted the quadratic model to express the length from the pruning period to flowering, in relation to the doses of garlic extract; we then obtained the maximum point of the function with the $7 \%$ garlic extract dose (Fig. 1). We emphasize the possibility of using the garlic extract, seeking other production systems that do not accept the use of hydrogen cyanamide, since it is a toxic product $[26,27]$.

The use of $2 \%$ hydrogen cyanamide promoted a 21 days anticipation of sprouting, when compared to the control treatment. This fact may be interesting, as it allows an early harvest in more economically favorable times, because the production does not coincide with the harvest peak in production regions of São Paulo state. This result is also interesting when we consider the phytosanitary aspect, for the concentration of harvests happens in times of lower rainfall. Both the hydrogen cyanamide and the garlic extract treatments promoted an anticipation and higher concentration of the production peak, when compared to the control treatment. We found that, in the production cycles of 2011 and 2012, respectively, the production peak of the control treatment happened from $12 / 11$ to $14 / 1$ and from $19 / 11$ to $14 / 1$. In the hydrogen cyanamide and garlic extract treatments, the production peak was anticipated in 15 days in the year of 2011 and in 20 days in the year 2012 (Table 2).
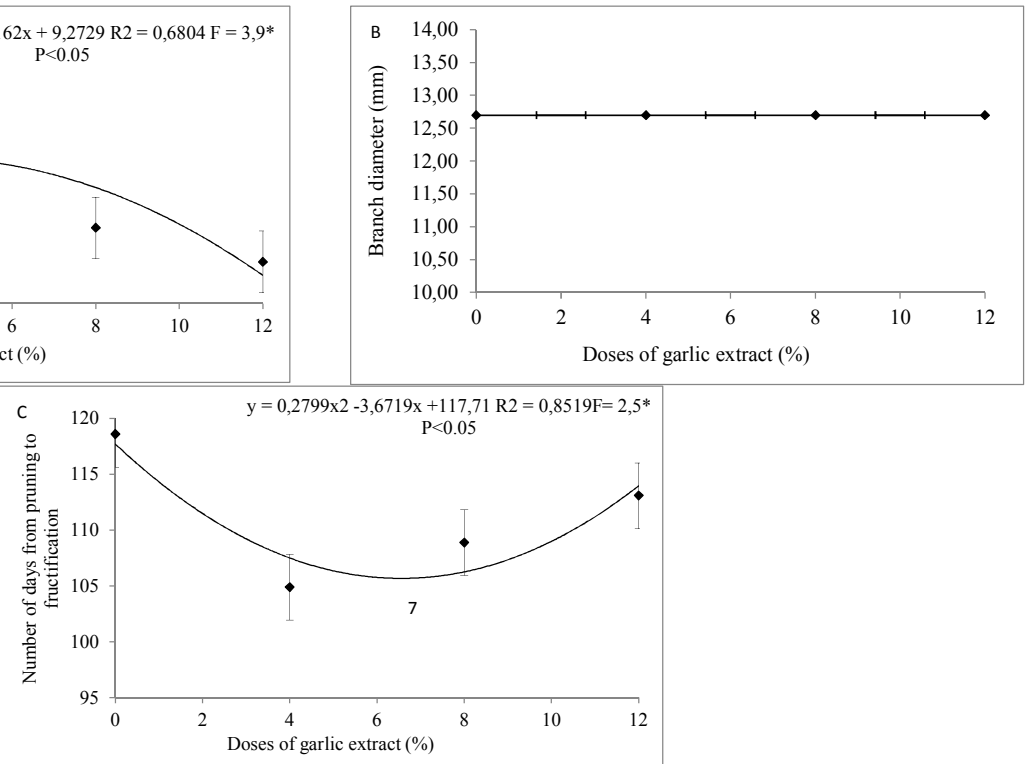

Fig. 1. Number of shoots per plant (A), average branch diameter (B) and number of days from pruning to fructification (C) peak of the fig tree, subjected to doses of garlic extract. FCA/UNESP/Botucatu 2011/12 and 2012/13 
Table 1. Mean results of the cycle's length from pruning to fructification, number of shoots per plant and diameter of secondary branches of the fig tree submitted to doses of garlic extract and hydrogen cyanamide in two production cycles. FCA/UNESP/Botucatu, 2011/12 and 2012/13

\begin{tabular}{lllll}
\hline Compound & Dose (\%) & $\begin{array}{l}\text { From pruning to } \\
\text { fructification (days) }\end{array}$ & $\begin{array}{l}\text { Number of shoots } \\
\text { per plant }\end{array}$ & $\begin{array}{l}\text { Diameter of } \\
\text { branches (mm) }\end{array}$ \\
\hline Hydrogen cyanamide & 2 & $98 \mathrm{~B}$ & 9.7 & 13.3 \\
Garlic extract & 0 & $119 \mathrm{~A}$ & 9.1 & 13.8 \\
Garlic extract & 4 & $105 \mathrm{AB}$ & 10.0 & 12.1 \\
Garlic extract & 8 & $109 \mathrm{AB}$ & 8.8 & 12.4 \\
Garlic extract & 12 & $113 \mathrm{AB}$ & 8.5 & 12.5 \\
DMS & & 17,0 & 3.2 & 3.0 \\
Standard error & & 3.77 & 0.71 & 0.65 \\
Cycle & & & \\
2011/12 & 107,9 & $8.6 \mathrm{~B}$ & $12.1 \mathrm{~B}$ \\
2012/13 & 109,4 & $9.8 \mathrm{~A}$ & $13.6 \mathrm{~A}$ \\
DMS & 4,0 & 0.6 & 1.1 \\
Standard error & & 1.42 & 0.21 & 0.37 \\
CV 1 (\%) & & 17,0 & 37.9 & 25.0 \\
CV 2 (\%) & & 10,1 & 17.3 & 22.8 \\
\hline
\end{tabular}

Measurements followed by different letters differ from each other by the Tukey test at $5 \%$ probability. $(P<0.05)$

Table 2. Period from the beginning, peak and end of harvest of the fig tree subjected to doses of garlic extract and hydrogen cyanamide in two production cycles. FCA/UNESP/Botucatu, 2011/12 and 2012/13

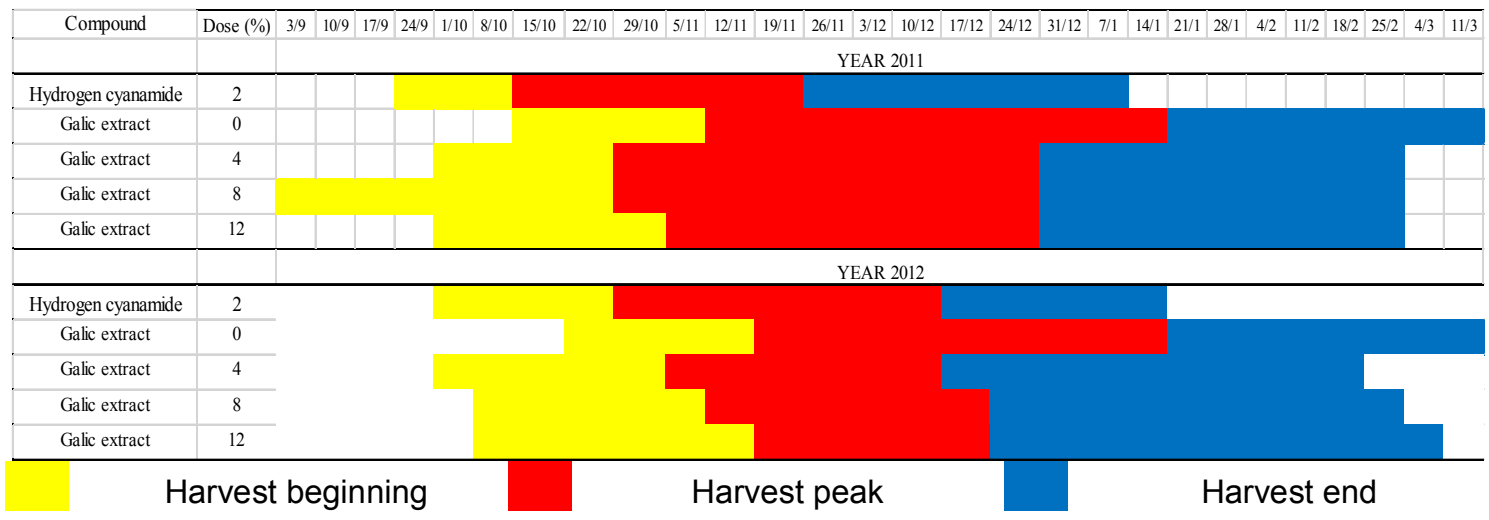

Norberto et al. [28] confirmed the beneficial effects of $2 \%$ hydrogen cyanamide and the anticipation of pruning time. Plants treated with hydrogen cyanamide, pruned in May, provided a first crop of green figs early in the offseason, which allowed the anticipation of the pruning period, associated to the use of the compound. Ohland et al. [29] evaluated the application of 5 , $10,15,20$ and $25 \mathrm{~mL} \mathrm{~L}^{-1}$ hydrogen cyanamide in the sprouting of fig tree cuttings. The researchers attributed the best response for sprouting to the application of hydrogen cyanamide and favorable hormonal balance.

In Morocco, a traditional fig producing country, Oukabli and Mekaoui [1] reported a very short period for the dormancy breaking of fig trees in cultivars from Morocco, Italy and Spain, and a longer period for the cultivars from France. The authors observed a gap between the leaf abscission and the beginning of sprouting that varied from 95 to 115 days, according to the evaluated cultivars. They have also reported that the number of $\leq 7,2^{\circ} \mathrm{C}$ cold hours was 450 hours in the first year of evaluation and 400 hours in the second year. The results obtained in this study indicate that the fig tree cv. Roxo de Valinhos had good sprouting, regardless of the use of compounds for breaking the dormancy (Table 1). 
Caetano [5] had also reported on the dormancy of the fig tree; the researcher compared the crops in different situations: crops in the northern hemisphere (temperate zone), in subtropical climate regions of the southern hemisphere and new crops in tropical climate. In regions of intense cold, environmental signs of the autumn's end and low temperature would bring the plants to rest, with shoot dormancy. However, the fig tree is able to resume vegetative growth immediately after the ceasing of adverse environmental conditions, or to not get into dormancy if there are no environmental adversities. This suggests that the endodormancy manifests itself very tenuously or it is absent in this species - and that the stoppage of growth during the winter would happen, in this case, to provide the survival of the species in severe cold.

For the variable number of shoots per plant, there was no difference between the hydrogen cyanamide treatments and the garlic extract treatments. However, considering the garlic extract treatments, we have adjusted the quadratic regression model to express the rise in the number of shoots with the doses of garlic extract - and the $4 \%$ dose showed the best results (Fig. 1). The beneficial effects of garlic extract on the dormancy breaking of temperate climate and bud breaking were already reported by other authors $[17,13,18,12,27]$.

There was no significant difference between the hydrogen cyanamide and garlic extract compounds for the average diameter of secondary branches, but there was difference between the production cycles: in 2011/12, the diameter was smaller $(12.1 \mathrm{~mm})$, when compared to 2012/13 (13.6 mm) (Table 1). This fact may be explained by the annual growth of the plants that were two years old (cycle 2011/2012) and three years old (cycle 2012/13). Leonel and Tecchio [23] also observed these responses on the fig threes' growth, according to the progressive production cycles. In plants of the cultivar Roxo de Valinhos, conducted with six productive branches, they reported an average diameter of $10.96 \mathrm{~mm}$ on secondary branches of plants that were 3 years old, and $16.23 \mathrm{~mm}$ on 4 years old plants.

According to Silva et al. [30], the fig tree branches, as well as the branches of other fruit trees that usually form the upper canopy layers, are the plants' storage organs and can show increased productivity. The authors also emphasize that the adequate supply of water and nutrients are the main determinants for the growth of branches. The results obtained in this research corroborate the authors' affirmation, allowing us to conclude that the effects of compounds for the dormancy breaking happen on the induction and standardization of sprouting, and have no effects on the branches' diameter growth [9].

There was no difference in using hydrogen cyanamide and garlic extract for the production and number of fruits per plant; we obtained the average values ranging from 4.8 to $6.1 \mathrm{~kg} \mathrm{plant}^{-1}$ and from 88 to 104 fruits plant $^{-1}$ (Table 3), respectively. For the variable fresh mass of fruits, the application of $2 \%$ hydrogen cyanamide was superior to the $12 \%$ garlic extract dose. There was higher production, higher number of fruits per plant and fresh mass of fruits in the production cycle of $2011 / 12$. This was already expected, since these plants are respectively two and three year old plants. For this reason, it was opted for the evaluation of the two cycles' averages. Leonel and Tecchio [23], in Botucatu (SP), reported that fig tree plants pruned in July and sprayed with $2 \%$ hydrogen cyanamide presented the highest average number of fruits and the highest estimate productivity, confirming the product's efficiency for the region.

Considering the isolated effect of garlic extract, it was adjusted the quadratic regression model to express the production rise and the number of fruits per plant, with function's maximum points of $3 \%$ and $6 \%$ garlic extract, respectively (Fig. 2). It should be noted that the highest production obtained with the $3 \%$ dose is more favorable to the producer, because it implies lower production costs than the acquisition and application of the product.

Plants sprayed with $4 \%$ and $8 \%$ garlic extract and $2 \%$ hydrogen cyanimide produced fruits with similar equatorial diameter, with higher values than those obtained with the control treatment, which presented fruits with smaller equatorial diameters $(45 \mathrm{~mm})$. For the longitudinal diameter, we obtained the highest value from the $4 \%$ garlic extract treatment $(59 \mathrm{~mm})$. The $2011 / 12$ production cycle presented, on average, fruits with larger equatorial diameter $(49 \mathrm{~mm})$ and longitudinal diameter $(55 \mathrm{~mm})$. There was no difference between the treatments with hydrogen cyanamide and garlic extract for the relation equatorial diameter/longitudinal diameter of fruits (Table 4). 
Concerning the effect of the garlic extract doses on the dimensions of fruits, we adjusted the quadratic regression model to express the rise in longitudinal and equatorial diameters of fruits, with the function's maximum points of $5 \%$ and $7 \%$ garlic extract, respectively (Fig. 3). There was a linear increase in the relation ED/LD of fig tree fruits with the increasing doses of garlic extract (Fig. 3). The values for the relation were, for all treatments, lower than 1.0, which indicates the formation of round-shaped fruits, presenting always the same average $10 \%$ smaller equatorial diameter than the longitudinal diameter [31]. This is a positive aspect, since the consumer markets have higher preference for the rounder fruits of the cv. Roxo de Valinhos.

Table 3. Mean production results, number of fruits per plant and fresh mass of fruits from the fig tree Roxo de Valinhos, subjected to doses of garlic extract and hydrogen cyanamide in to production cycles. FCA/UNESP/Botucatu/SP, 2011/12 and 2012/13

\begin{tabular}{lllll}
\hline Compound & Dose (\%) & Production (kg plant $^{-1}$ ) & $\begin{array}{l}\text { Number of } \\
\text { fruits per plant }^{-1}\end{array}$ & $\begin{array}{l}\text { Fresh mass of } \\
\text { the fruit (g) }\end{array}$ \\
\hline Hydrogen cyanamide & 2 & 6.1 & 104 & $59.5 \mathrm{~A}$ \\
Garlic extract & 0 & 5.2 & 88 & $58.0 \mathrm{AB}$ \\
Garlic extract & 4 & 5.6 & 102 & $56.8 \mathrm{AB}$ \\
Garlic extract & 8 & 4.9 & 92 & $53.1 \mathrm{AB}$ \\
Garlic extract & 12 & 4.8 & 90 & $52.7 \mathrm{~B}$ \\
DMS & 1.5 & 24.8 & 6.8 \\
Standard error & 1.54 & 5.49 & 1.51 \\
Cycles & & & \\
$2011 / 12$ & $4.9 \mathrm{~B}$ & $86.8 \mathrm{~B}$ & $54.8 \mathrm{~B}$ \\
2012/13 & $5.8 \mathrm{~A}$ & $103.3 \mathrm{~A}$ & $57.2 \mathrm{~A}$ \\
DMS & 0.4 & 6.4 & 1.6 \\
Standard error & 0.15 & 2.30 & 0.56 \\
CV 1 (\%) & & 31.5 & 28.3 & 13.2 \\
CV 2 (\%) & & 21.7 & 18.7 & 7.8 \\
\hline Measurements followed by different letters differ from each other by the Tukey test at 5\% probability. $(P<0.05)$
\end{tabular}

Table 4. Mean results of equatorial diameter, longitudinal diameter and relation equatorial diameter/longitudinal diameter of fruits from the fig tree Roxo de Valinhos, subjected to doses of garlic extract and hydrogen cyanamide in two production cycles. FCA/UNESP/Botucatu. 2011/12 and 2012/13

\begin{tabular}{|c|c|c|c|c|}
\hline \multirow[t]{2}{*}{ Compound } & \multirow[t]{2}{*}{ Dose (\%) } & \multicolumn{2}{|c|}{ Diameter of fruits (mm) } & \multirow[t]{2}{*}{ Relation DE/DL } \\
\hline & & Equatorial (ED) & Longitudinal (LD) & \\
\hline Hydrogen cyanamide & 2 & $51 \mathrm{~A}$ & $55 \mathrm{~B}$ & 0,92 \\
\hline Garlic extract & 0 & $45 \mathrm{C}$ & $53 \mathrm{~B}$ & 0,86 \\
\hline Garlic extract & 4 & $50 \mathrm{AB}$ & $59 \mathrm{~A}$ & 0,85 \\
\hline Garlic extract & 8 & $48 \mathrm{AB}$ & $53 \mathrm{~B}$ & 0,91 \\
\hline Garlic extract & 12 & $48 \mathrm{~B}$ & $52 \mathrm{~B}$ & 0,92 \\
\hline DMS & & 2,7 & 3,4 & 0,07 \\
\hline Standard error & & 0.60 & 0.75 & 0.02 \\
\hline \multicolumn{5}{|l|}{ Cycle } \\
\hline $2011 / 12$ & & $49 \mathrm{~A}$ & $55 \mathrm{~A}$ & 0,9 \\
\hline $2012 / 13$ & & $48 \mathrm{~B}$ & $54 \mathrm{~B}$ & 0,9 \\
\hline DMS & & 1,2 & 1,4 & 0,02 \\
\hline Standard error & & 0.43 & 0.50 & 0.01 \\
\hline CV $1(\%)$ & & 6,1 & 6,8 & 9,0 \\
\hline CV $2(\%)$ & & 6,8 & 7,1 & 7,6 \\
\hline
\end{tabular}



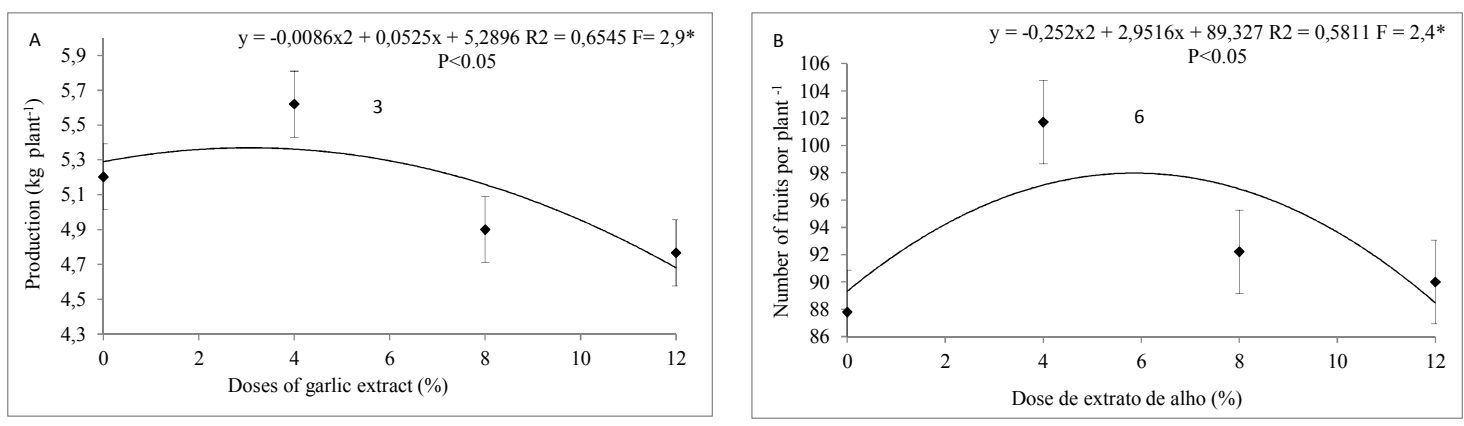

Fig. 2. Production (A) and number of fruits per plant (B) of the fig tree Roxo de Valinhos subjected to doses of garlic extract in two production cycles. FCA/UNESP/Botucatu. 2011/12 and 2012/13
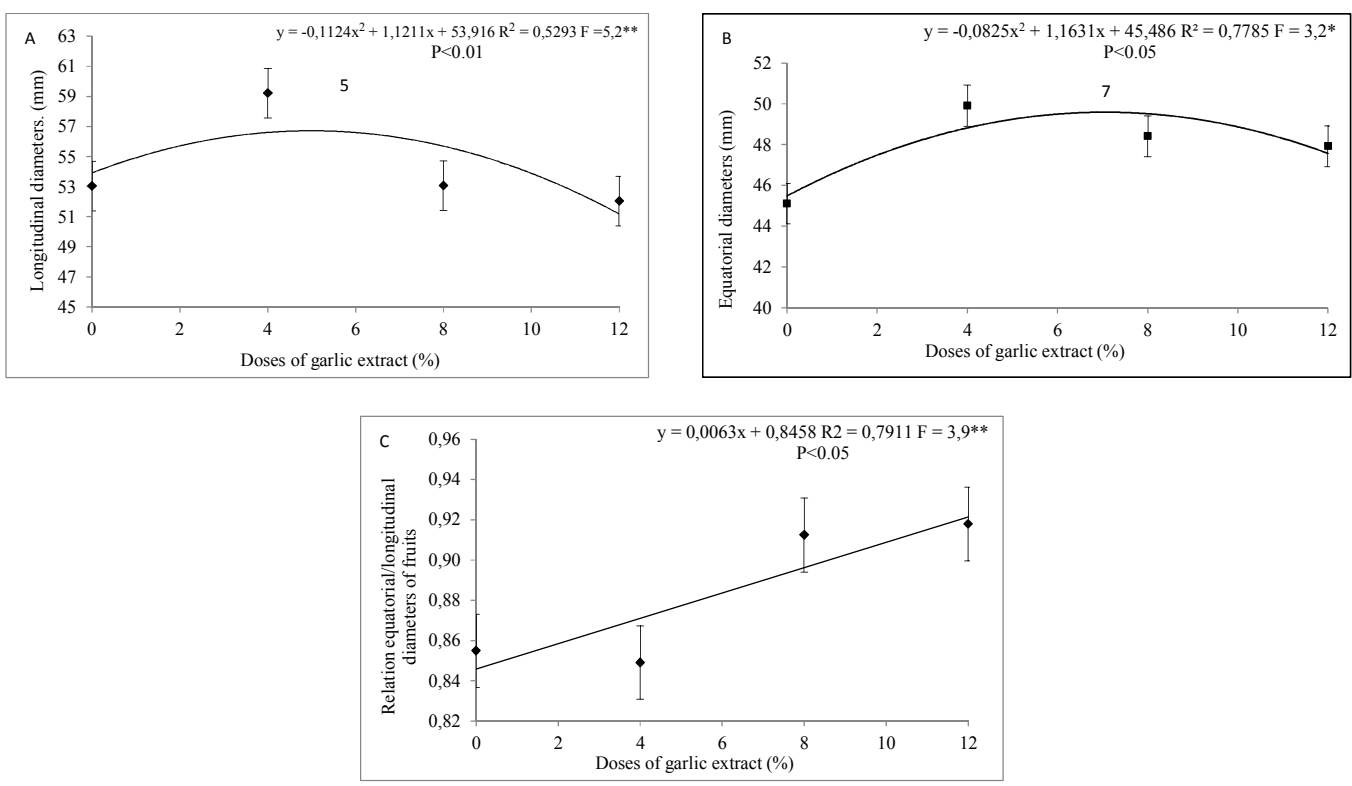

Fig. 3. Logitudinal diameters (A), equatorial diameters (B), relation equatorial/longitudinal diameters (C) of fruits from the fig tree Roxo de Valinhos subjected to doses of garlic extract in two production cycles. FCA/UNESP/Botucatu. 2011/12 and 2012/13

\section{CONCLUSION}

There was no difference between the compounds and doses evaluated for the variables diameter of secondary branches, number of shoots and fruits per plant and production. The application of hydrogen cyanamide $2 \%$ promoted anticipation of sprouting, and in conjunction with the garlic extract, it also promoted a concentration of the productive period. There was no difference in using hydrogen cyanamide and garlic extract for the production and number of fruits per plant. The estimated garlic extract dose that provided the highest production per plant was $3 \%$. The garlic extract may be recommended as a sprouting inductor on fig trees under the growing conditions in subtropical climate of the São Paulo state, Brazil.

\section{COMPETING INTERESTS}

Authors have declared that no competing interests exist.

\section{REFERENCES}

1. Oukabli A, Mekaoui A. Dormancy of fig cultivated under Moroccan conditions. American Journal of Plant Sciences. 2012; 3:473-479. 
2. Souza AP, Silva AC, Leonel S, Escobedo JF. Basal temperature and thermal time the fig tree pruned at different times. Brazilian Journal of Fruticulture. 2009; 31(02):314-322.

3. Vossen PM, Silver D. Growing temperature tree fruit and nut crops in the home garden. California: university of California Research and Information Center/ The California Backyard Orchard. 2000;91.

4. Botti C, Frank L, Pratt DI, Morales B. The effect of climatic conditions on fresh fig fruit yield, quality and type of crop. Acta Horticulturae. 2003;605:37-43.

5. Caetano LCS. The cultivation of the fig tree in a hot climate region. In: Pommer CV, Caetano LCS, Pereira MCT, Oakdays MS, Pacheco DD. Production of temperate fruit trees in tropical regions. Handout minicourse of the nineteenth Brazilian Congress Of Fruit- Brazil Fruits: health to the world. 2006;14-21.

6. Rodrigues MGF, Correa LS, Boliani AC. Evaluation hp fig mutant selections Purple Valinhos. Brazilian Journal of Fruticulture. 2009;31(3):771-777.

7. Pedro Jr MJ, Barbosa W, Rolim GS, De Castro JL. Season of flowering and chilling hours for peach and nectarine trees. Brazilian Journal of Fruticulture. 2007; 29(3):425-430.

8. Settimi L, Davanzo F, Faraoni MG, Richmond D, Calvert GM. Update: Hidrogen cyanamide-related IInesses Italy, 2002-2004. Morbidity and Mortality Weekly Repor. 2005;54:405-408.

9. Mani F, Bettaieb T, Doudech N, Hannachi C. Effect of hydrogen peroxide and Thiourea on dormancy breaking of microtubers and field-grown tubers of potato. African Crop Science Journal. 2013;21(3):221-234.

10. Sagredo KX, Theron KI, Cook NC. Effect of mineral oil and hydrogen cyanamide concentration on dormancy breaking in 'Golden Delicious' apple trees. South African Journal of Plant and Soil. 2005; 22(4):251-256.

11. Mcartney SJ, Walker JTS. Current situation and future challenges facing the production and marketing of organic fruit in Oceania. Acta Horticulturae. 2004;638: 387-396.

12. Vargas I, Corrales C, Martinez $\mathrm{M}$. Compounds derived from garlic as bud induction agent in organic farming of table grape. Chilean Journal Agricultural Research. 2008;68:94-101.

13. Botelho RV, Pavanello AP, Pires EJP, Terra MM, Müller MML. Effects of chilling and garlic extract on bud dormancy release in Cabernet Sauvignon grapevine cuttings. American Journal of Enology and Viticulture. 2007a;58:402-404.

14. Segantini DM, Leonel S, Ripardo ACS, Auricchio MGR. Use of growth regulators to break dormancy and its influence on budding, flowering and yield in the black mulberry. Brazilian Journal of Fruticulture. 2011;E:275-280.

15. Kubota N, Miyamuki M. Breaking bud dormancy in grapevines with garlic paste. Journal of the American Society for Horticultural Science. 1992;117:898-901.

16. Pinto M, Lira V, Ugalde H, Perez F. De la Physiology latency yolks vid them: actuales hypotheses. Santiago: Universidad de Chile. 2007;16.

Available:http://agronomia.uchile.cl/extensi on/serviciosyproductos/gie/publicaciones. (Accessed: January 17, 2014)

17. Kubota N, Mattheus MA, Takahagi T. Effects of garlic preparations and calcium and hydrogen cyanamides on bud break of grapevines grown in greenhouses. American Journal of Enology and Viticulture. 2000;51:409-414.

18. Botelho RV. Garlic extract effect of apple bud break. Brazilian Journal of Fruticulture. 2007b;29(2):403-405.

19. Kuskoski MS, Ahasuerus AG, Morales MT, Fett R. Wild tropical fruit and frozen fruit pulps: antioxidant activity, polyphenols and anthocyanins. Rural Science. 2006;36: 1283-1287.

20. Hassimoto NMA, Mora RV, Cordenunsi BR, Lajolo FM. Physico-chemical characterization and bioactive compounds of blackberry fruits (Rubus $\mathrm{sp}$ ) grown in Brazil. Science and Alimentary Technology. 2008;28:702-708.

21. Köppen W. Das geographische System der Klimate. In. Köppen W, Geiser R. (Eds): Handbuch der Klimatologie. Gebrüder Bornträger, Berlin, 1936;1:1-44.

22. Cunha AR, Martins D. Climate classification for the municipalities of San Manuel and Botucatu, SP. Irrigation. 2009; 14(1):1-11.

23. Leonel S, Tecchio MA. Seasons pruning and use of irrigation in fig "Purple Valinhos'. Bragantia. 2010;69(3):571-580. 
24. Damatto JR ER. Planning and installation of the orchard. In: LEONEL S, Sampaio AC. (Eds). The fig tree. São Paulo: Editora UNESP. 2011;167-176.

25. Ferreira DF. Sisvar: a computer statistical analysis system. Science and Agrotechnology. 2011;35(6):1039-1042.

26. Oliveira OR, Biasi LA, Skalitz R, Poltroniei AS. Breaking dormancy of pear 'Hosui' with lime sulfur in two drive systems. Brazilian Journal of Agricultural Sciences. 2009;4(4):383-387.

27. Maldonado CC, Martinez-Telles MA, Gardea AA, Orozco-Avitia A, ArispuroVargas I. Organic alternative for breaking dormancy in table grapes grown in hot regions. American Journal of Agricultural and Biological Sciences. 2010;5(2):143147.

28. Norberto PM, Chalfun NNJ, Pasqual M, Veiga RD, Mota JH. Effect of pruning time, hydrogenated cyanamide and irrigation in anticipated production of green figs. Brazilian Agricultural Research. 2001; 36(11):1363-1369.

29. Ohland T, More Bad, Chagas EA, Barbosa W, Dalastra IM, Kotz TE. Rooting of hardwood cuttings of apical fig tree 'Roxo de Valinhos' with application of IBA and hydrogen cyanamide. Brazilian Journal of Fruticulture. 2009;31(1):273-279.

30. Silva AC, Leonel S, Souza AP, Souza ME, Tanaka AA. Fig tree growth under different conditions. Journal of Tropical Agriculture. 2011;41(4):539-551.

31. Silva AC, Souza AP, Leonel S, Souza ME, Tanaka AA. Physical characterization and chemical correlation of the fruits of mango cultivars in San Manuel, São Paulo. Magistra. 2012;24:15-26.

(c) 2015 Leonel et al.; This is an Open Access article distributed under the terms of the Creative Commons Attribution License (http://creativecommons.org/licenses/by/4.0), which permits unrestricted use, distribution, and reproduction in any medium, provided the original work is properly cited.

Peer-review history:

The peer review history for this paper can be accessed here: http://www.sciencedomain.org/review-history. php?iid=1210\&id=5\&aid=9647 